\title{
Cuora mouhotii (Gray 1862) - Keeled Box Turtle
}

\author{
INDRANEIL DAS ${ }^{1}$, Timothy E.M. MCCORMACK ${ }^{2}$, \\ Peter Paul van DiJK ${ }^{3,4}$, Ha V. Hoang ${ }^{2}$, and Richard P.J.H. StruiJK ${ }^{5}$ \\ ${ }^{1}$ Institute of Biodiversity and Environmental Conservation, Universiti Malaysia Sarawak, \\ 94300 Kota Samarahan, Sarawak, Malaysia [idas@ibec.unimas.my]; \\ ${ }^{2}$ Asian Turtle Program (ATP) of Indo-Myanmar Conservation (IMC), Room 1806, C14 Bac Ha Building, To Huu \\ Road, Tu Liem District, Hanoi, Vietnam [tmccormack@asianturtleprogram.org,hvha@asianturtleprogram.org]; \\ ${ }^{3}$ Global Wildlife Conservation, PO Box 129, Austin, Texas 78767 USA [ppvandijk@globalwildlife.org]; \\ ${ }^{4}$ Turtle Conservancy, 49 Bleecker Street, New York, New York 10012 USA; \\ ${ }^{5}$ RAVON Foundation (Reptile, Amphibian \& Fish Conservation Netherlands), Natuurplaza, \\ Toernooiveld 1,6523 ED Nijmegen, Netherlands [r.struijk@ravon.nl]
}

Summary. - The Keeled Box Turtle, Cuora mouhotii (Family Geoemydidae), is a small (carapace length up to ca. $250 \mathrm{~mm}$ ), once poorly-known terrestrial species. Recent extensive research on the species in its natural habitat in northern Vietnam and Hainan, China, has significantly increased available knowledge of the species. Cuora mouhotii is a highly terrestrial turtle from the mesic forests of Southeast Asia. Two subspecies have been described, and intergradient populations are known. Relatively widespread, it is apparently abundant nowhere. Omnivorous, at least in captivity, the species is highly carnivorous in the wild but will also take fruit. Clutch size ranges from 1-9 eggs, with egg dimensions ca. $41 \times 26 \mathrm{~mm}$; incubation period in captivity varies from 82 to 120 days. Major threats to the species are loss of forest habitat from logging and commercial trade for Traditional Chinese Medicine and food. To a lesser extent capture for local consumption and both national and international pet trade are factors threatening this species.

Distribution. - Bangladesh, Bhutan, China, India, Laos, Myanmar, Thailand (?), Vietnam. Ranges across Southeast Asia from Bhutan and northeastern India in the west to central Vietnam and southern China in the east, possibly discontinuous in Thailand.

Synonymy.-Cyclemys mouhotii Gray 1862,Pyxidea mouhotii,Emys mouhotii,Geoemyda mouhotii, Cuora mouhotii.

SuBSPECIES. - Two currently recognized: Cuora mouhotii mouhotii (Mouhot's Keeled Box Turtle; southeastern China, northern Laos, northern Vietnam, possibly northern Thailand) (synonymy: Pyxidea mouhotii mouhotii) and Cuora mouhotii obsti (Obst's Keeled Box Turtle; central and southern Vietnam) (synonymy: Pyxidea mouhotii obsti Fritz, Andreas and Lehr 1998). Records from Bangladesh, Bhutan, northeastern India, and Myanmar may refer to an undescribed lineage.

StaTuS. - IUCN 2016 Red List: Endangered (EN A1d+2d, assessed 2000); TFTSG Draft Red List: Critically Endangered (CR, assessed 2011); CITES: Appendix II (as Cuora spp.).

Taxonomy. - Cuora mouhotii was described by Gray (1862), based upon a series of seven syntypes from "Lao Mountains, in Siam" (presumably the Luang Prabang mountain range on the border between Thailand and Laos; King and Burke 1989). The specific epithet celebrates Henri Mouhot [1826-1861], the French explorer of Indochina who was the first Westerner to see Angkor Wat (Cambodia). The following year, Gray (1863) erected a new genus, Pyxidea, for this species; the etymology ("Pyxis-like") presumably alludes to the similarity of the plastral hinging and pigmentation to the condition in the testudinid genus Pyxis.

The name Pyxidea achieved only erratic usage for a long time-Boulenger (1889), for example, persisting with Cyclemys mouhotii-and Bourret (1941) also us- ing Cyclemys, but perpetrating an unfortunate error in his spelling of the specific name (mohouti). Even after Smith and James (1958) reaffirmed the validity of Pyxidea (with a further unfortunate error in the species name (mouboti), McDowell (1964) placed mouhotii in the genus Geoemy$d a$, along with such miscellanea as Cuora flavomarginata and Geoemyda spengleri. Nonetheless, these were rather profoundly dissimilar taxa; McDowell's usage attracted little if any following, and the genus Pyxidea was soon re-established. Pronunciation of the specific patronym, however, has been a challenge for many anglophone biologists; the "t" in the French name Mohout is silent, but not in the Latin name mohoutii, and most render the name in a form akin to "ma-hooty". More recently, Honda et al. (2002) and Stuart and Parham (2004) synonymized 


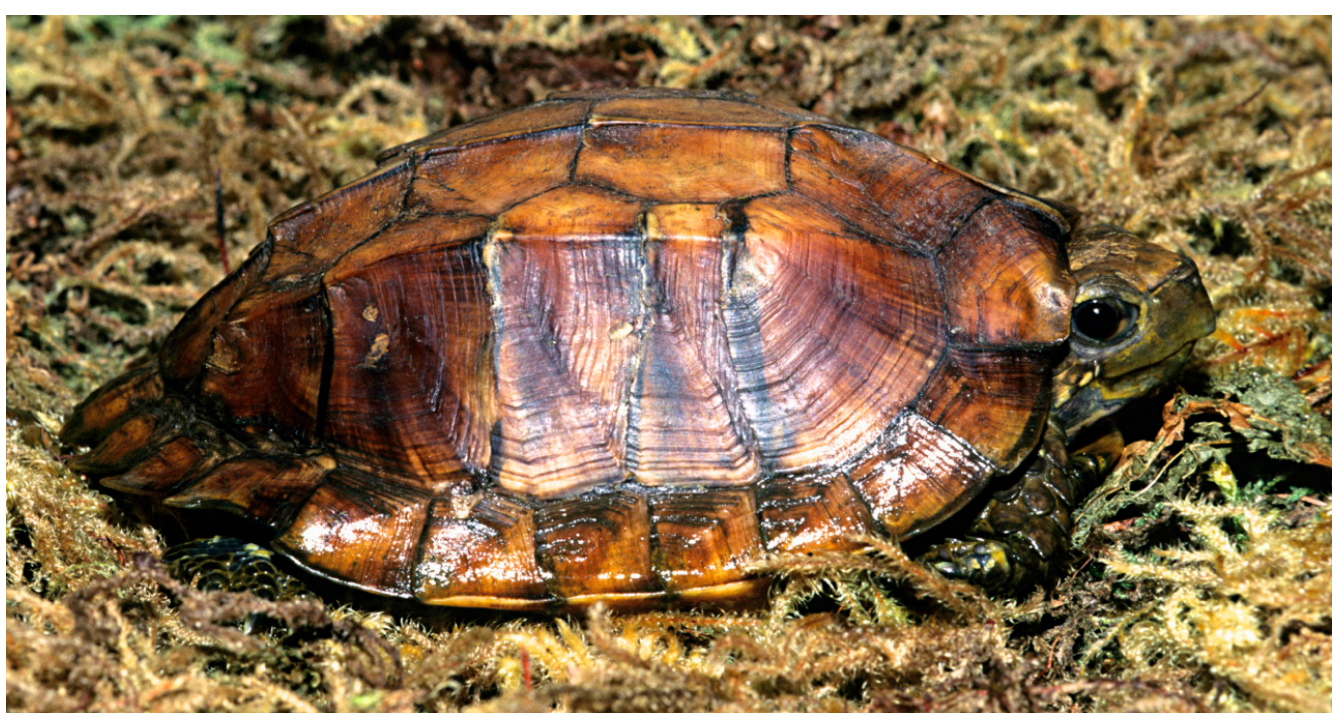

Figure 1. Subadult Cuora mouhotii from southeastern China. Photo by Indraneil Das.

Pyxidea under Cuora based on genetic analysis, a classification which has become widely accepted (Turtle Taxonomy Working Group 2014).

Geographic variation is poorly documented. It is possible that individuals from the northern part of the range, in China, may have broader, less robust, lower shells than those from further south. Fritz et al. (1998) described a new subspecies, obsti, from Annam, Central Vietnam, characterized by its rounder shell and plastral pattern, comprising radiating black blotches. Nonetheless, intergradient populations have been reported from the Ha Tinh and Quang Binh provinces of Vietnam by Fritz et al. (2002). Extensive surveys by the Asian Turtle Program (ATP) in north and central Vietnam support this, with $C$. m. obsti seen in Thua-Thien Hue Province and $C$. $m$. mouhotii in Nghe An Province, limiting the intergrade to the region within Ha Tinh, Quang Binh, and Quang Tri provinces (Struijk et al. 2016; McCormack, unpubl. data). Throughout the remainder of the species' range, intergrade areas have not been defined but overlap appears to occur (Struijk et al. 2016). Records from Bangladesh, Bhutan, northeastern India, and Myanmar (Platt et al. 2013) may refer to another distinctive lineage. Although Fritz et al. (1998) already mentioned this possibility, it was merely based on a single Indian museum specimen that displayed a plastral pattern distinct from the eastern subspecies. However, it has since been shown that plastral patterns throughout the western range of the species shows wide variation, even within India (Struijk et al. 2016). Since great phenotypic variability occurs, phylogeographic studies should be conducted to delineate other potential lineages within the species (Struijk et al. 2016).
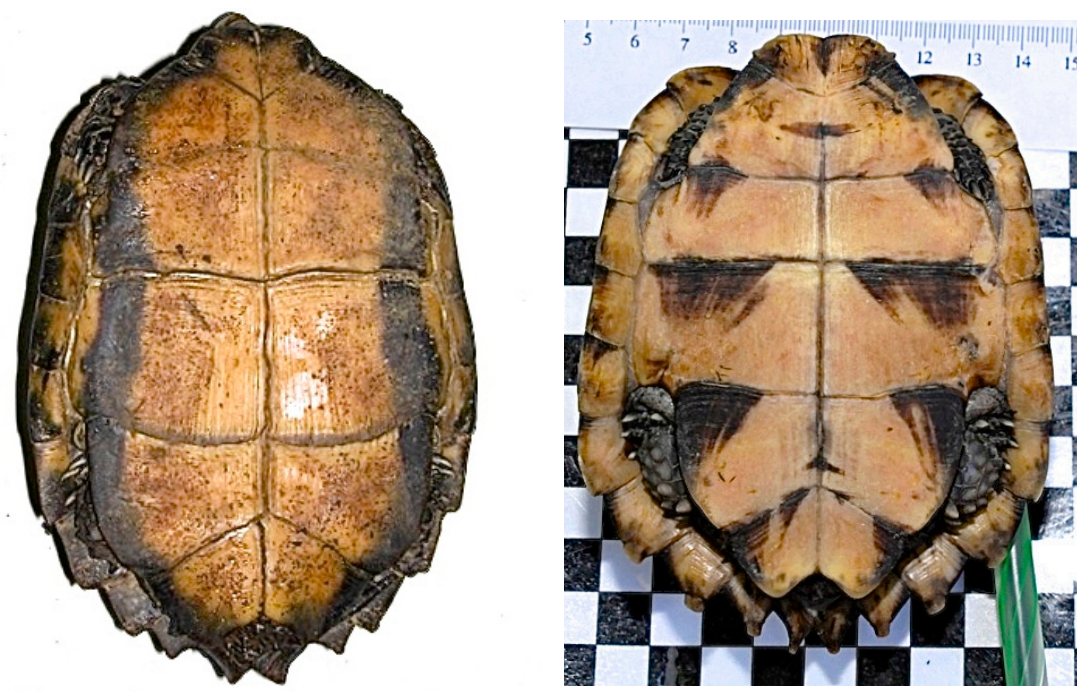

Figure 2. Left: Adult female wild-caught adult Cuora mouhotii mouhotii from Cuc Phuong National Park, Vietnam. Photo by T. McCormack, ATP. Right: Adult female C. m. obsti, from local trade in Quang Tri, Vietnam. Photo by Nguyen Thanh Luan, ATP. 
In the wild $C$. mouhotii is known to hybridize with Cuora galbinifrons, C. bourreti, C. trifasciata, and C. picturata and some hybrids were initially described as a valid subspecies, Cuora galbinifrons serrata Iverson and McCord 1992 (Parham et al. 2001; Stuart and Parham 2004; Shi et al. 2005; Struijk and Blanck 2016).

Description. - The carapace is high, rather narrow, with a clear midline dorsal keel running the length of the vertebral scutes; from this keel the carapace is considerably flattened laterally into the costal scutes on both sides where secondary keels also occur, thus providing the species with one of its common names, the Three-keeled Box Turtle. The posterior marginals are markedly serrated and scalloped anteriorly. The sides of the shell are typically almost straight and posteriorly divergent, so that the carapace is wider posteriorly than anteriorly. The vertebral keel is sharp, and the lateral keels are distinct, and mark the abrupt transition from the almost horizontal upper parts of the costal scutes and the steep, often slightly concave central and lower parts of these scutes. The nuchal scute is long and narrow, and the width of the vertebral scutes is subequal through the series, although vertebrals 1 and 5 may be slightly narrower. The costal scutes are posteriorly "raked," with the intercostal seams sloping backwards sharply from their lower to upper extremities. Costal 1 is the largest on each side. Growth annuli are usually quite evident, except in the oldest individuals. Within a single population some considerable variation can be seen in the height of the carapace, with some animals having lower and more flattened shells (McCormack, pers. obs. in Cuc Phuong National Park, Vietnam).

The midline carapace length (MCL), though often about $185 \mathrm{~mm}$ in wild adult animals, can reach up to ca. $250 \mathrm{~mm}$. The largest individual on record was a captive

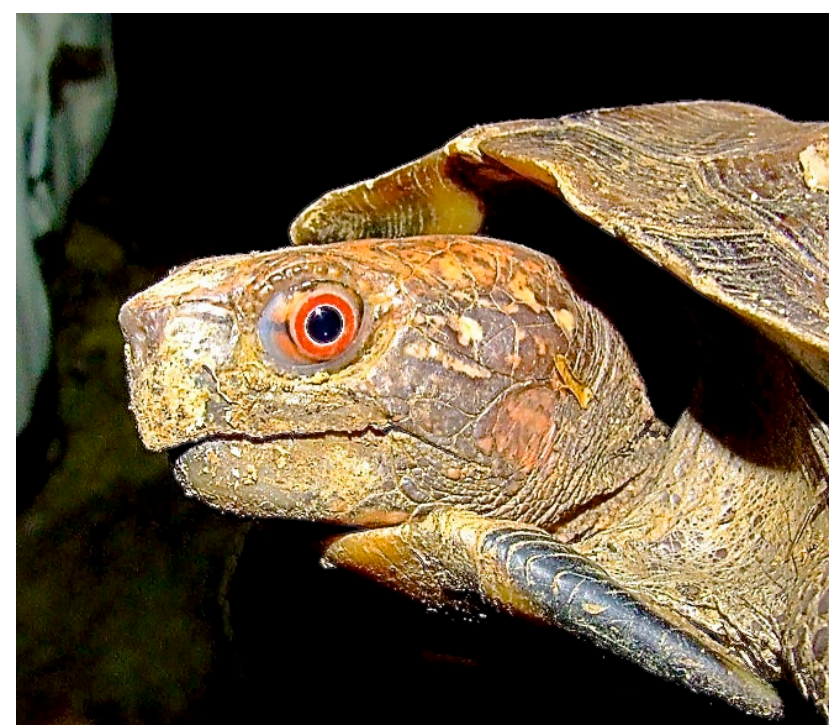

Figure 3. Adult male Cuora mouhotii mouhotii from Cuc Phuong National Park,Vietnam. Photo by T. McCormack, ATP. specimen at the Turtle Conservation Centre (TCC) in Cuc Phuong National Park, Vietnam-a large male that was transferred from Soc Son Rescue centre in Hanoi, Vietnam, when he measured $189 \mathrm{~mm}$ MCL and continued to grow up to $257 \mathrm{~mm}$ MCL. However, it does appear unusual to find individuals measuring greater than $200 \mathrm{~mm}$ in length.

The plastron is relatively large, with a well-formed hinge between the hyo- and hypoplastra, the lateral edges of which are close to the seam between marginals 5 and 6 . The
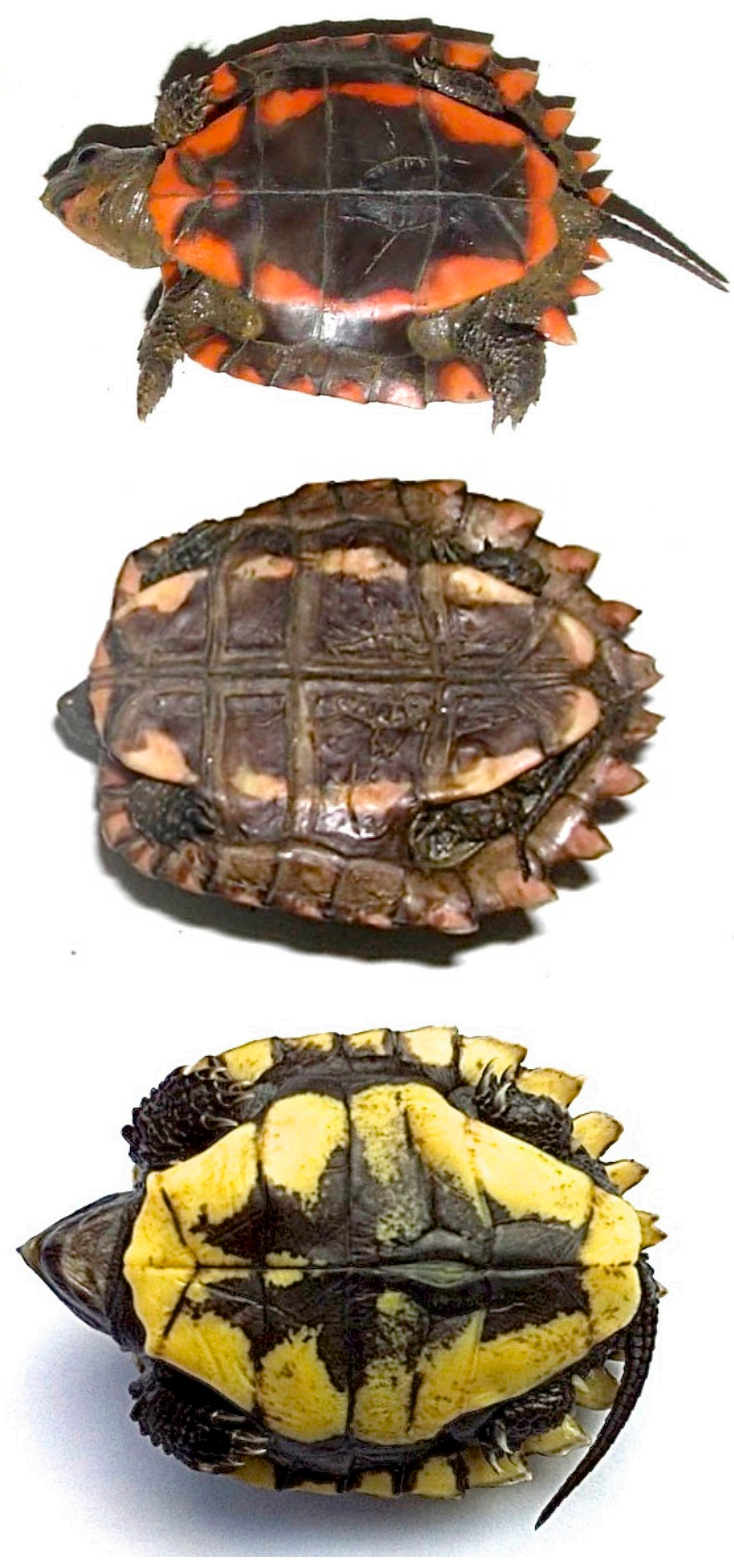

Figure 4. Top: A wild-caught hatchling/yearling Cuora $\mathrm{m}$. mouhotii from Cuc Phuong National Park, Ninh Binh, northern Vietnam, displaying typical orange peripheral plastral markings. Photo by T. McCormack, ATP. Middle: A juvenile wild-caught C. m. mouhotii from Cuc Phuong National Park in Vietnam, although this individual has lost the bright orange red hatchling coloration of hatchlings it still has not developed the full characteristic of adult animals with, black peripheral markings, almost the inverse of what is seen here. Photo by T. McCormack, ATP. Bottom: A hatchling Cuora m. obsti displaying its more yellow plastral coloration. Photo by R. Struijk. 


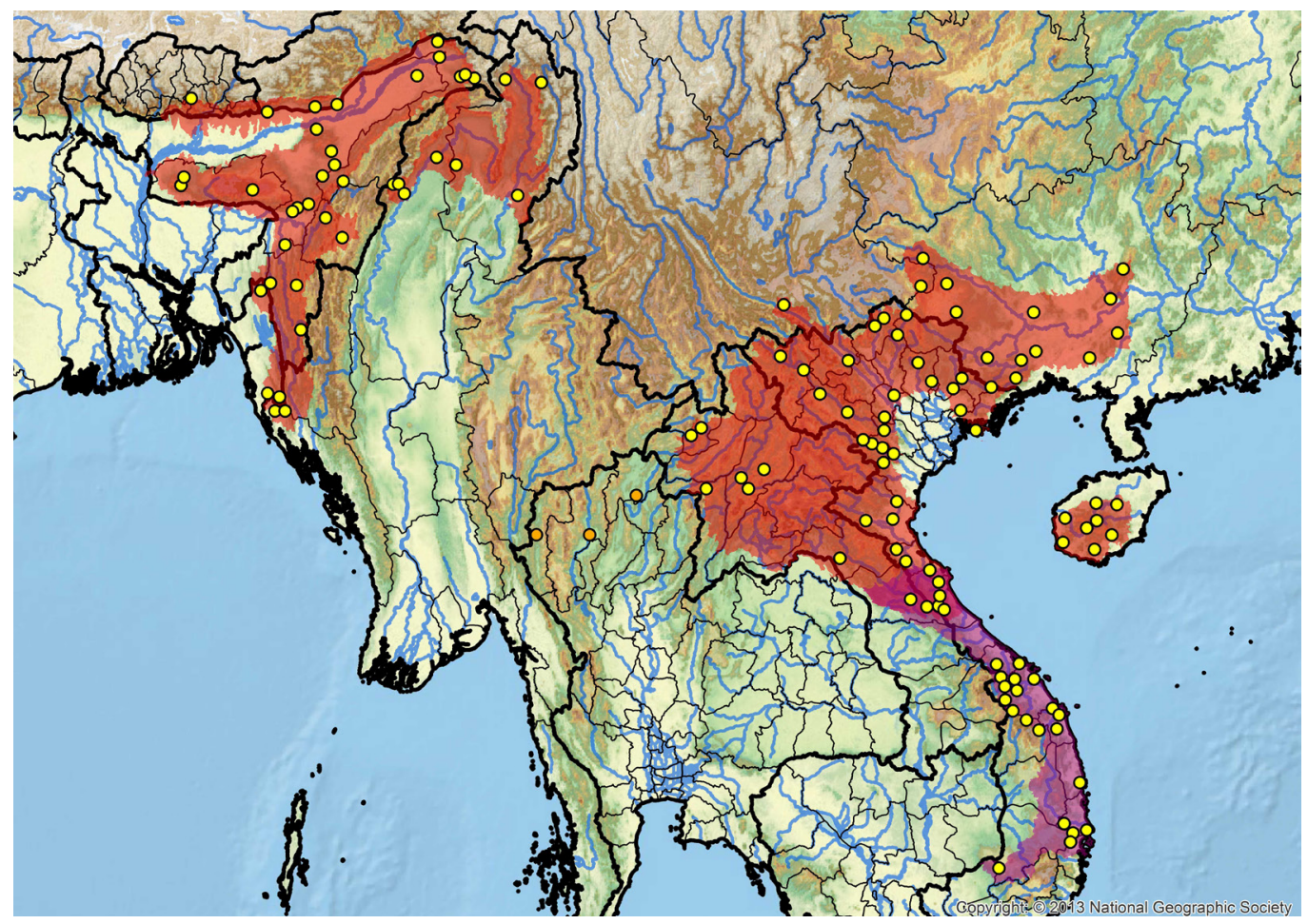

Figure 5. Distribution of Cuora mouhotii in Southeast Asia. Yellow dots = museum and literature occurrence records of native populations based on Iverson (1992), plus more recent and authors' data; orange dots = probable market specimens. Red shading = projected historic distribution of $C . m$.mouhotii (western populations may represent a distinct lineage), purple shading $=C$. $m$.obsti, overlap $=$ intergrades. Distributions based on GIS-defined level 10 HUCs (hydrologic unit compartments) constructed around verified localities and then adding HUCs that connect known point localities in the same watershed or physiographic region, and similar habitats and elevations as verified HUCs (Buhlmann et al. 2009; TTWG 2014), and adjusted based on authors' subsequent data.

hinge has well-developed kinetic function but the plastron is too small to close the shell openings completely. The posterior lobe is significantly larger than the anterior, and the posterior lobe also occupies the greater part of the bridge. The gular region is slightly extended, with a constricted base. The gulars are large, with the intergular seam approximately the same length as the interhumeral. The interabdominal seam is the longest along the plastral midline, with the interpectoral only slightly shorter. A moderate, usually angular, xiphiplastral notch is present.

The head is large, with considerable jaw adductor muscles to the rear of the head, combined with a strongly hooked upper jaw, likely adaptations to facilitating the crushing and eating of land snails, which seem to be an important part of the diet. Large, rounded, slightly imbricate scales are present on the outer surface of the forelimbs and on the soles of the hind feet. The tail is rather long, especially in juveniles, with tubercles at its base that are prominent in the adults.

The carapace is often dark brown but can be a variety of shades ranging from light yellow to almost black, often with darker areas just ventral to the lateral keels. The plastron is yellow, buff, or light brown, sometimes immaculate, but more often with a variable degree of dark markings. The plastron markings are dependent on the subspecies and are the most easily identifiable character- istics that differentiate the subspecies. Cuora m. mouhotii most often has dark brown/black peripheral markings in bands, sometimes broken or as occasional spots, around the outer edge of the plastron (Fritz et al. 1998; Becker 2011; Struijk and Blanck 2016). When only partially expressed, these markings are usually adjacent to the bridges, but in other individuals the entire plastral periphery may bear linear black markings, with black pigment on the ventral aspects of the marginals also, and with some "bleeding" of this pigment on to the carapacial aspect of the marginals. In contrast, $C . m$. obsti has black marking that can range from feather-like markings to almost completely black, often triangular in shape, radiating out from where the plastral scutes abut one another (Farkas and Fritz 1998; Struijk and Blanck 2016). Plastron markings on older animals can be very worn, with individuals appearing entirely yellow or with a yellow central area and peripheral areas worn to a darker brown/black that might make some older C. m. obsti look like C. m. mouhotii. A secondary characteristic that distinguishes the subspecies is the carapace shape $-C$.m. mouhotii is more elongated than C. m. obsti, which is generally more rounded (Fritz et al. 1998; Struijk et al. 2016). The head is also brown to yellow, the temporals marked with one or two yellow spots or elongate, horizontal light streaks. Towards the neck, the head has elaborate vermiculations. 
The species has a complete series of neural bones; they are unusually wide and typically the anterior and middle elements are hexagonal with the short sides posteriorly, followed by a small, tetragonal element at position 5 or 6 , which in turn is followed by relatively small neurals in the form of hexagons with the short sides anteriorly. Two or three suprapygals may be present, the lowermost being large and wide. Occasionally, one or more neurals may be octagonal. Plastral buttresses are absent. Hatchlings of C. m. mouhotii often display bright orange/ red plastrons with generally dark black centers which is almost the inverse of the adults markings; whereas $C$. $m$. obsti hatchlings have a yellowish plastron with less abundant and less solid gray to black marking in the central parts. Based on these features both subspecies can probably be differentiated from one another (Struijk and McCormack, pers. obs.). Hatchling plastral patterns fade in time. Subadults show intercostal and mid-plastral fontanelles until a CL of about $110 \mathrm{~mm}$ is reached. There is no alternation in width of the lower ends of the pleural bones. The bridge is unossified, the part opposite the forelobe of the plastron being smooth while that opposite the hindlobe is rougher. A small bony spur penetrates the hinge for a short distance on each side.

The skull shows a complete, albeit delicate, zygomatic arch, and a well-developed upper rhamphotheca that is slightly hooked but lacks tomial topography or ridging. The cervical vertebrae are relatively elongate, stout, with an amphicoelous eighth cervical showing ginglymoidy at both ends, and a biconvex sixth.

Sexual dimorphism is modest, with little difference between the dorsal aspects of adult males and females, either in terms of size or morphology. However, males have a slight plastral concavity more prominent in larger individuals, and a clearly thicker-based tail with a more distal vent.

The karyotype is $2 \mathrm{n}=52$ (Bickham and Carr 1983; Guo 1997).

Distribution. - The Keeled Box Turtle ranges over southern Bhutan, northeastern India, northern and southwestern Myanmar, Laos, Vietnam, and through southern China to Hainan. It also occurs in northeastern and southeastern Bangladesh, but the records from northern Thailand (cited by many authors, including Nabhitabhata et al. 2000) are suspect as being trade specimens from markets (van Dijk and Palasuwan 2000). No records are yet reported from Cambodia but it is possible the species occurs in the extreme northeastern region (David Emmett, pers. comm.). Within Vietnam the southern extent of the species range is currently recognized as Khanh Hoa province (ATP, unpubl. data).

Habitat and Ecology. - The overall range of the species appears to encompass tropical moist forest, es-

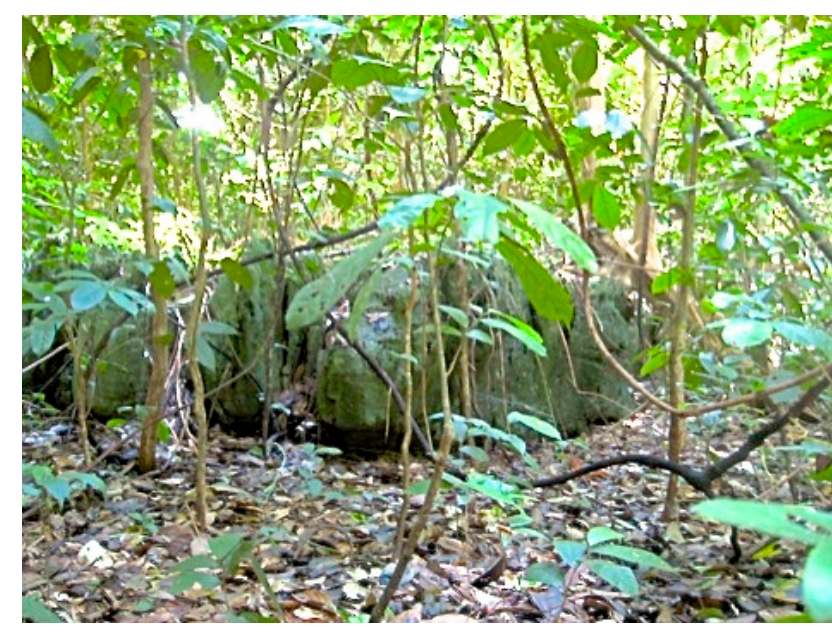

Figure 6. Typical forest habitat seen for Cuora $\mathrm{m}$. mouhotii in Cuc Phuong National Park, Vietnam. Photo by T. McCormack, ATP.

pecially the dipterocarp formations, and at least some specimens have come from mountainous terrain (Pope 1935; Platt et al. 2000; Wangyal et al. 2012); although, in Vietnam at least, this species is considered typical of low country, being replaced by Geoemyda spengleri at higher altitudes. In Vietnam observation of the species in trade and the wild indicates a preference for broadleaf evergreen forest on limestone karst such Cuc Phuong National Park or Phong Nha Khe Bang where the species is relatively abundant, although the species is not exclusively restricted to limestone areas. In Cuc Phuong National Park it was found to be the only turtle species present in large areas of the limestone karst hill forest that is seasonally very dry, in river valley areas where permanent water occurs and other species are also present.

One animal was taken from the rocky banks of a stream (Das 1987), although during four years of weekly radio tracking 13 animals at Cuc Phuong National Park, Vietnam, the species was never observed entering water (McCormack et al., in press a). In captivity, the species is seldom observed in water when adequate land area is provided. Soaking, when observed, may be associated with extreme heat or stress and is a behavior that can be an indication of poor health.

During a four-year radio tracking study from 20032007 at Cuc Phuong National Park, the home range of C. m. mouhotii was found to be 3.95 ha with significant variation seen between individuals and years (McCormack et al., in press a). The species was observed utilizing the habitat seasonally, spending warm and wet summer months in forest valleys with largely soil substrate, in contrast winter months would be spent on rocky slopes in rock crevices where animals would hibernate or estivate for an average of 23 weeks (McCormack et al., in press a). In the wild in northern Vietnam, animals were most frequently encountered at the onset of the wet sea- 
son, May-June, although the species was readily found throughout the warmer months, March-September (McCormack et al. 2006). In a 2007-2008 study on daily activity patterns of the species in the wild during three distinct seasons, activity was found to cease at temperatures below $18^{\circ} \mathrm{C}$ while an average daily distance of $11.92 \mathrm{~m}$ was seen in August compared to only $1.28 \mathrm{~m}$ in December which corresponded to a daily average temperature of $23.8^{\circ} \mathrm{C}$ in August and only $16.7^{\circ} \mathrm{C}$ in December (Hoang et al., in press).

Reproduction. - Nesting in Hainan, China, was from May-July with a peak in mid-June (Wang et al. 2011). Clutch size according to Tikader and Sharma (1985) is 1-3. At the Turtle Conservation Centre (TCC) in Cuc Phuong National Park, Vietnam in 2002 and 2003 six clutches of eggs of C. m. mouhotii were observed, ranging from 1-7 (mean 3.17) eggs per clutch, and clutches of 4-5 are not uncommon (McCormack and Bui, unpubl. data). Eggs are relatively large and brittle-shelled, the dimensions of which have been given as $40 \times 25 \mathrm{~mm}$ by Ewert (1979), 51-56 x 25-27 mm by Tikader and Sharma (1985), and 38-45 x 21-29 mm (10-22 g), averaging $41.37 \times 26.00 \mathrm{~mm}(17.53 \mathrm{~g})(\mathrm{n}=19)$ by McCormack and Bui (unpubl. data). Hatchlings have a CL of about $35 \mathrm{~mm}$ (Ewert 1979); one from Assam, northeastern India had a CL of $39.2 \mathrm{~mm}$ (Das 1987), and Becker (2011) reported the average mass of nine hatchlings as $9.96 \mathrm{~g}$. In the semiwild enclosures at the TCC in Cuc Phuong National Park, northern Vietnam C. m. mouhotii were observed nesting in May and June, based on 5 documented nestings in 2002 and 2003 (McCormack and Bui, unpubl. data).

Diet. - Observations during a 2004-2005 telemetry study in Cuc Phuong National Park highlighted snails and mushrooms as the major food items, though their availability was reduced during the dry season (McCormack 2005). Snail shell fragments are frequently found in feces of wild animals (McCormack, pers. obs.), with snails being particularly abundant in the rock limestone environments often associated with the species.

Population Status. - The species does not appear to be abundant, but it has a relatively wide range. As part of a mark-recapture study in Cuc Phuong National Park, Vietnam in 2008-2009 the species could be found regularly but required considerable effort, with 34.90 hours of search time required to find a single animal $(0.0287$ turtles found per man hour of effort) (Hoang et al. 2010). Animals of all age classes including hatchlings and juveniles have been encountered, but the dense tropical forest habitat in which the species occurs coupled with its well-camouflaged appearance and cryptic behavior (often hiding under leaf litter or logs or in small rocky caves), means the encounter frequency and assessment of population in the species is more challenging than for other less secretive species. Anecdotal information from local interviews indicates that populations of the species have declined dramatically throughout the range. Within Vietnam it is frequently reported that while the species was regularly encountered prior to the 1980s when wildlife traders started requesting the species, now it is considered rare, and even with hunting dogs only small numbers can be collected in a week.

Threats to Survival. - Logging of rainforests for timber or agriculture, capture for the international pet trade, capture for food and traditional medicine are all noted as factors impacting the species (Choudhury 1996, 1998, 2001), and export from various nations of Southeast Asia through northern Vietnam for consumption in China for food and traditional medicine are generally considered to be the greatest threat that has reduced populations of this species (Platt et al. 2000; Altherr and Freyer 2000; Ziegler 2002; Stuart and Platt 2004).

Habitat Loss. - Dependent on good quality evergreen tropical forest, C. mouhotii has been directly impacted by forest loss in its Southeast Asian range countries. Sodhi et al. (2010) estimated that already by 2004 only about $41-44 \%$ of Southeast Asia's original forest cover remained. The greatest chance for the species' survival likely lies with the populations surviving in many of the protected areas where it occurs, such as Song Thanh Nature Reserve, Quang Nam, Vietnam, Phong Khanh Khe Bang National Park, and Jianfengling Nature Reserve, Hainan, China (Gong et al. 2006). However with less than $10 \%$ of southeast Asia's forest under protection this will only represent a small fragment of the species' historical range (Sodhi et al. 2010). Unfortunately, persistent hunting and poaching within protected forest areas means the long-term survival of the species is at risk. An increased economic value combined with increasingly fragmented and degraded habitats put this species under an ever-growing extinction risk, as is already the case for most other Asian tortoise and freshwater turtle species.

Trade. - The regional trade in C. mouhotii is significant, with much of the trade destined for Chinese markets where it is often seen for sale (Shi et al. 2004). With improved wildlife protection in regional countries, such as Vietnam, most of this trade is now prohibited and as such, conducted illegally. Zhou and Jiang (2008) noted that $C$. mouhotii was one of the top seven species that made up $87 \%$ of all turtles exported from China, with exports reported at between 170,000-290,000 individuals per year from 1998-2001. It should be noted that within these data there were no detailed volumes given specifically for $C$. mouhotii. For the same period the number of live individual turtles imported into China was 400,000 $21,000,000$ per year, but without clear details on the volumes of specific species. Importantly, the vast majority 
of trade in tortoises and freshwater turtles coming into China from Laos, Vietnam and Myanmar (where most of the C. mouhotii in that trade trade originated) is illegal and not adequately documented.

Between 1994 and 1999 Vietnam alone reported 6,560 legal exports of $C$. mouhotii as reported by CITES (Hendrie 2000). However, this is likely to be a vast underestimation of the real number of $C$. mouhotii traded. During this same period, Hendrie (2000) reported the species was still commonly seized along northern routes, mainly during the spring. While trade confiscations involving the species have been limited to small numbers observed during the intervening years, in September 2015 a shipment of 237 tortoises and freshwater turtles of five species was confiscated in transit in Hanoi; of these, over 50 were $C$. m. mouhotii. Fortunately these animals were successfully confiscated and are being quarantined at the TCC in Cuc Phuong National Park (McCormack et al. 2015).

Farming. - Although some farms have reported successful breeding of C. mouhotii in captivity, it is not always clear what volumes are being produced (Shi and Parham 2001). Also, farm hatchlings may likely be captive hatched instead of captive bred, meaning that they originate from gravid wild-caught females (Struijk and Blanck 2016). Information collected from farms should be treated with caution unless clear and supported documentation can be shown. Shi et al. (2008) stated that 140,100 C. mouhotii were maintained in Chinese farms at that time, with 50,000 individuals for sale per year. However, it has been observed that some farms report falsely positive breeding results while actually depending on wild-caught animals being 'laundered' as farmed. In some large-scale farms in China C. mouhotii has been reported to hybridize with Cuora trifasciata (Zhou et al. 2006).

International Pet Trade. - The species appears to have become more desirable in the pet trade in the past decade as it has become more rare. Historically it was a relatively inexpensive turtle, costing only US \$10 in November 1995, and \$25 in May 1997. Between 1989 and 1992 no specimens of C. mouhotii were reportedly imported into the USA but from 1993-1997 a total of 1,127 animals were imported, prior to the listing of the species on CITES Appendix II in 1998 (Telecky 2001). The price has risen steadily since - in 2012 males were offered for $\$ 275$ and females $\$ 375$ and by 2015 even captive-bred hatchlings were selling for $\$ 400$. This increase could in part be due to the change in CITES listing with imports of wild-caught individuals now prohibited with a zero quota since 2013. However, smuggling of this and other Asian species into Europe and the USA is still reportedly taking place in small numbers, although few confiscations are made. Once in Europe trade of wild-caught animals is poorly regulated and animals can be easily transferred between Schengen Area states. The growing popularity of chelonians as pets within the Asian region, including Indonesia, China, and Thailand may also result in an increased demand for C. mouhotii (Gong et al. 2009).

National Pet Trade. - While the species has often been associated with the international pet trade and is now highly sought after in Europe, the USA and Japan, C. mouhotii has also been a preferred species in the national pet trade in Vietnam. In the live animal trade in Hanoi, the species used to be commonly seen in the pet section at Dong Xuan market in the early 2000s for just a few US dollars. Within Vietnam the species is still sought for the domestic pet trade in major cities such as Hanoi, while in rural areas individuals are still consumed. Much of the trade in tortoises and freshwater turtles in Vietnam and elsewhere in southeast Asia now occurs online in forums and on Facebook, and in Vietnam C. mouhotii is still often offered online for between $\$ 10-15$ per individual, often small animals (Nguyen et al. 2013; McCormack and Nguyen 2014; McCormack 2015).

The species has been observed in rural communities, during interviews around Ngoc Son Nature Reserve in northern Vietnam, reportedly kept as pets, but large individuals are normally sold to traders quickly (McCormack et al. 2011). Some locals report that small individuals are kept in the hope of raising them to sell or farm.

Consumption and Use. - In some localities in Laos and Vietnam local consumption is reported (Stuart and Platt 2004). Historically the consumption of tortoises and freshwater turtles in Vietnam was reported by many ethnic minorities to be opportunistic. Hardshelled species were not actively sought as food but were reportedly eaten if encountered; softshelled Trionychidae were more actively sought and preferred. Some hunters have even reported an aversion to turtles as a food source due to traditional beliefs in which encountering turtles in the forest was considered unlucky. However, C. mouhotii and many other tortoise and freshwater turtle species are consumed and shells of animals are still often observed in rural communities, particularly in mountainous areas. In Quang Nam province, central Vietnam in 2006 the species was offered for sale at between $\$ 1-5$ per $\mathrm{kg}$, averaging just $\$ 4.08$ per $\mathrm{kg}$ in an area where the species is both sold into the wildlife trade and consumed locally (McCormack et al. 2006).

While residents in rural communities throughout the species' range continue to eat $C$. mouhotii it is likely this volume is far smaller than that traded for export to the major consuming markets in China. The demand for tortoises and freshwater turtles in China has been the major driving force behind the Asian turtle crisis (van Dijk et al. 2000). Artner and Hofer (2000) reported seeing hun- 
dreds of individuals of both subspecies of $C$. mouhotii in a large market in Guangzhou, China in 2000, and Hagen et al. (2011) reported still observing the species in Chinese food markets. Although not specifically sought after for Traditional Chinese Medicine (TCM), C. mouhotii is still being sold for TCM purposes in China and to a lesser extent in Vietnam, with animals observed in wet food markets also likely to be used in TCM, as such markets provide a source for both forms of consumption and likely for the pet trade also (Gong et al. 2009).

In India, where the species is relatively rare, commercial collecting of $C$. mouhotii is uncommon, although it is eaten by some villagers (Das et al. 2009; Ahmed and Das 2009). In Myanmar, many Naga (an ethnic classification including a number of Indo-Mongoloid tribes) of the Naga Hills, Myanmar, consider C. mouhotii flesh toxic and its consumption is said to cause gall bladder ailments, severe abdominal cramps, and nervous system disorders (Platt et al. 2013).

Conservation Measures Taken. - The species has been recorded from the Namdapha Tiger Reserve (and proposed Biosphere Reserve) in Arunachal Pradesh, northeastern India. In Thailand, this and many other species have legal protection under the Wild Animals Reservation and Protection Act B.E. 2535 1992, which prohibits all trade (domestic and export) in "Protected and Reserved" wild animals. In Myanmar, it is protected under the Myanmar Fisheries Law (1993), as well as under Myanmar Wildlife Law (1994) (see Maung and Ko Ko 2002). In Vietnam, C. mouhotii is not listed under either of two Vietnam Government Decrees (32/2006/ND-CP and 160/2013/ND-CP) that list endangered, precious and rare species that are prioritized for protection (including other turtle species). It is given some protection under the broader 1991 law on forest protection and development, which applies to protected areas and forest resources. In China the species is listed as category II as part of the nationally protected terrestrial wild animals that are beneficial, or with important economic and scientific research value (2000), under the Chinese Wildlife Protection Law. In Laos C. mouhotii is listed as category II under the MAR Regulation 0360 (2003) on the management of National Biodiversity Conservation Areas and aquatic and wild animal conservation. In Myanmar all tortoises and freshwater turtles are protected under the Myanmar Wildlife Protection Law (1994) and Fisheries Law (1993) which prohibits hunting and trade of turtles.

The species has also been listed as Endangered on the IUCN Red List since 2000 (www.iucnredlist.org), and has recently been recommended for possible uplisting to Critically Endangered (TTWG 2014). As a result of recently being included in the genus Cuora, the species was included in Appendix II of CITES to protect it from overexploitation by the international food and pet trade. In 2013 the CITES listing for C. mouhotii changed to Appendix II zero quota, meaning international trade in wild caught animals should be more heavily regulated. Unfortunately this does not prevent the majority of regional trade that is unregulated and occurs across the porous borders of Laos-Vietnam, Vietnam-China, Laos-China, and Myanmar-China.

In Vietnam the monitored release of a small group of $C$. mouhotii with radio transmitters assessed the survival of long term trade animals that had been rescued and kept in captivity for a long time. Of three animals released, all survived two years post release (McCormack et al., in press b). This supports release as a viable option for confiscated animals of this species as long as healthy animals are released into suitable habitat.

Captive assurance colonies are maintained at a number of locations. In Cuc Phuong National Park, Vietnam, the TCC has held a significant captive assurance colony for the species since 1998. In Bangladesh, a small breeding group has been established at the Bhawal NP in 2016 (S.C. Rahman,pers. comm.). The Turtle Survival Alliance (TSA) also maintains an assurance colony of the species at their Turtle Survival Center (TSC) in South Carolina, USA.

Conservation Measures Proposed. - Cuora mouhotii would benefit from improved protection under national laws. It warrants inclusion in Schedule I of the Indian Wildlife (Protection) Act 1972, as its habitat is vulnerable to destruction due to clear-cutting for timber and shifting cultivation. The species would also benefit from inclusion in Vietnamese National law. With a significant decline in wild populations throughout its range, it also warrants uplisting from Endangered to Critically Endangered on the IUCN Red List under criterion A4, as it is suspected that the population of $C$. mouhotii has decreased by more than $80 \%$ within a three-generation period and the causes of reduction have not ceased (principally demand for the wildlife trade). Cuora mouhotii is currently not listed in the top 25 most endangered turtles worldwide, and does not even make the top 40 list (Turtle Conservation Coalition 2011); however, this does not reflect the threats this species is facing but rather is the result of the even more severe extinction crisis facing many tortoises and freshwater turtles as a taxonomic group.

Viable populations likely survive in existing protected areas where the species is reported to occur throughout its range, such as Song Thanh Nature Reserve in Quang Nam, Sao La Nature Reserve in Thu Thien Hue, Cuc Phuong National Park in Ninh Binh and many others. However, the relentless and intensive hunting pressure faced within the protected habitats will continue to contribute to the regional decline and possible localized loss of the species. More needs to be done with national and local 
wildlife protection authorities, including at the site level, to raise the profile of $C$. mouhotii and other threatened chelonian species to promote greater protection. Unfortunately, in many of the range states underlying weaknesses within wildlife and habitat protection combined with rural poverty has resulted in inadequate protection of many taxa. Support could be given to priority sites for the species, for example Cuc Phuong National Park where existing research and the TCC provide a solid foundation for a long-term in-situ conservation program.

Continued monitoring of regional and international pet trade remains critically important with the increase in chelonian pet trade in Asia in particular. Cuora mouhotii is already being seen as a popular species within the pet trade in Vietnam and the situation is possibly similar in China.

Since captive breeding has increased in volume over the last decade, maintenance of geographic genetic patterns is important. Effective and targeted conservation efforts such as captive breeding and the establishment of nature reserves aimed at protecting this species are highly desirable, but need to be based on adequately understanding its phylogeography. More genetic and phenotypic studies of C. mouhotii are therefore urgently needed.

Captive Husbandry. - The species is increasingly common in captivity, with a number of breeders in Europe and USA (e.g., Becker 2011). Male C. mouhotii are aggressive when mating and should be kept individually except for mating periods; females can be housed together. Males will attempt to mate year-round but should only be paired with females for short intervals during spring and autumn.

Of note is the occurrence of parasitic ticks on the species when kept in captivity in range. When held in large numbers in tight quarters at the TCC in Vietnam it was found that the tick, Amblyomma geoemydae, could become very abundant and posed a possible health and disease vector risk to the animals (Robbins et al. 2006). Moving animals to more humid, less dry, enclosures seems to have reduced the occurrence of ticks, while manual removal of ticks was also effective. Ticks have also been found frequently on wild caught $C$. mouhotii in Cuc Phuong National Park.

Buskirk (1993) reported on a captive female that deposited five eggs on 4 September, and four about a year earlier, on 27 August, about a year after being separated from a male. The five-egg clutch was incubated in moist vermiculite at about $27^{\circ} \mathrm{C}$, and hatched $91-102$ (mean 96) days later, between $4-15$ December. Hatchlings measured about $40 \mathrm{~mm}$ each in CL and had an average mass of $12 \mathrm{~g}$. Pointet (1997) reported captive clutch sizes in the range of $1-5$, and incubation temperatures of 26 to $27^{\circ} \mathrm{C}$, with incubation period lasting 83 to 95 days. Hatchlings weighed $12 \mathrm{~g}$ and had CL of 35-40 $\mathrm{mm}$.
Clutch sizes in captivity ranged from 1-9 eggs (on average 4-6) (Buskirk 1993; Boonman 1995; Pointet 1997; van Rooijen 1998; Jakab and Sátorhelyi 2000; Felsner 2002; Wulfert 2008; Struijk 2010; Becker 2011). In general eggs are successfully incubated at $26-28^{\circ} \mathrm{C}$ but fluctuating temperature regimes between $23-30^{\circ} \mathrm{C}$ have also been reported to be successful (Buskirk 1993; Jakab and Sátorhelyi 2000; Hackethal in Schilde 2004; Struijk 2010; Davis 2011). Eggs generally hatch after 90-110 days (range 82-120 days) and hatchlings weigh circa 8-12 $\mathrm{g}$ and measure between 35 and $42 \mathrm{~mm}$ CL (Pointet 1997; Jakab and Sátorhelyi 2000; Felsner 2002; Struijk 2010).

Hatchlings start feeding after approximately one week and take small invertebrates such as earthworms, garden snails, woodlouse, buffalo worms, and small crickets. Adults are omnivorous and accept a wide variety of food items such as snails, slugs, fish, pinky mice, earthworms, Zophoba, shrimp, and also fruits and some vegetables; they even take large African Snails (Achatina fulica) if offered (McCormack, pers. obs.).

In captivity, the species burrows into the substrate, and Sachsse (1973) found that it could be brought to the surface by sprinkling water. Higher activity levels during rainfall were also noticed by Fischer et al. (2010). In semi-wild enclosures at the TCC, rock caves have been built to mimic natural habitat. Animals spend considerable time in these rock caves or buried under piles of leaf litter and brush and have also been observed nesting and depositing eggs in the substrate and soil in the caves. Struijk and Blanck (2015) reported hybridization in captivity with Cuora bourreti.

Current Research. - Long-term radiotracking in Cuc Phuong National Park, Vietnam, was undertaken from 2003 until 2009, when it was discontinued. In 20082009 mark-recapture studies were also undertaken in Cuc Phuong National Park. It would be feasible to reinitiate a conservation project on $C$. mouhotii within the park with microchipping (PIT tagging) of a wild population for monitoring. During annual student training held in the national park, short interview surveys are conducted that focus on the species. A study of the biology of the species, perhaps using the breeding population at Miao Zoo, Arunachal Pradesh, and free-ranging animals at the adjacent Namdapha Tiger Reserve, appears feasible. The species would also benefit from additional survey work, especially in Myanmar and northeastern India, to assess population status and phylogeographic patterns.

Acknowledgments. - Supported by the Centre for Herpetology, Madras Crocodile Bank Trust and Universiti Malaysia Sarawak. We thank Patrick David for supplying a French reference, Genevieve V.A. Gee for reading 
the manuscript, and Job Stumpel for advice. We would also like to thank Cuc Phuong National Park and the Turtle Conservation Centre (TCC), Ninh Binh, Vietnam, for supporting field research and captive assurance breeding of the species, in particular Bui Dang Phong, Hoang Van Thai, and Hao Do Thanh who have worked at the rescue center and supported ATP research activities. We would like to thank Nguyen Thanh Luan of the ATP for providing a photo, and Torsten Blanck and John Iverson for additional distributional data.

\section{LITERATURE CITED}

Ahmed,M.F. And DAs, A. 2009. Tortoises and freshwater turtles of Kaziranga National Park, Assam-diversity, distribution, conservation status. ENVIS Bulletin: Wildlife and Protected Areas 12(1):57-70.

Altherr, S. AND Freyer, D. 2000. Asian turtles are threatened by extinction. Turtle and Tortoise Newsletter 1:7-11.

Artner, H. And Hofer, A. 2001. Observations in the Qing Ping Free Market, Guangzhou, China, November 2000. Turtle and Tortoise Newsletter 3:14.

BeCKer, H. 2011. Bemerkungen zur zucht von Pyxidea mouhotii mouhotii und Pyxidea mouhotii obsti, sowie beobachtungen $\mathrm{zu}$ plastronfarbungen der jungtiere. Marginata 2011:48-55.

BICKHAM, J.W. AND CARR, J.L. 1983. Taxonomy and phylogeny of the higher categories of cryptodiran turtles based on a cladistic analysis of chromosomal data. Copeia 1983:913-932.

Boonman, J. 1995. Een gekielde Doosschildpad uit Zuidoost Azië, Pyxidea mouhotii. Lacerta 53(5):132-138.

Boulenger, G.A. 1889. Catalogue of the Chelonians, Rhynchocephalians, and Crocodilians in the British Museum (Natural History). British Museum (Natural History), London, 311 pp.

BourRET, R.L. 1941. Les tortues de l'Indochine. Institut Océanographique de l'Indochine, Hanoi, 235 pp.

Buhlmann, K.A., Akre, T.S.B., Iverson, J.B., Karapatakis, D., MitTermeIER, R.A., GEORGES, A., RHODIN,A.G.J., vAN DiJK, P.P., AND GibBons, J.W. 2009. A global analysis of tortoise and freshwater turtle distributions with identification of priority conservation areas. Chelonian Conservation and Biology 8(2):116-149.

BuskIRK, J. 1993. The NYTTS breeder's notebook. NYTTS NewsNotes 4(1):19.

Choudhury, A.U. 1996. The keeled box turtle Pyxidea mouhotii Gray - a new record for Manipur. Journal of the Bombay Natural History Society 93:590-591.

Choudhury,A.U.1998.Pyxideamouhotii(Gray) in southernAssamand Mizoram.Journal of the Bombay Natural History Society 95(3):511.

CHOUdHURY,A.U.2001.Some chelonian recordsfrom Mizoram.Journal of the Bombay Natural History Society 98:184-190.

Das, A., Saikia, U., Murthy, B.H.C.K., Dey, S., and Dutta, S.K. 2009. A herpetofaunal inventory of Barail Wildlife Sanctuary and adjacent regions, Assam, north-eastern India. Hamadryad 34(1):117-134.

DAS, I. 1987. Distribution of the keeled box turtle Pyxidea mouhotii (Gray). Journal of the Bombay Natural History Society 84:221-222.

DAVIS, S. 2011. Significant breedings. Turtle Survival Magazine 2011:20-23.

EwERT, M.A. 1979. The embryo and the egg: development and natural history. In: Turtles: Perspectives and Research. Harless, M. and Morlock, H. (Eds.). Wiley Interscience, New York, pp. 333-416.

FARKAS, B. AND FrITZ, U. 1998. On the identity of Rafetus swinhoei (Gray, 1873) and Pelochelys maculatus (Heude, 1880) (Reptilia: Testudines: Trionychidae). Zoologische Abhandlungen 50:59-75.
FELSNER, H. 2002. Welt-Erstnachzuchtbericht der Annam-Dornschildkrote Pyxidea mouhotii obsti Fritz, Andreas \& Lehr, 1998. Emys 9(1):4-21.

Fischer, I., WAHL, S., AND WeIMER, S. 2010. Research into the ecology of the Keeled Box Turtle (Cuora mouhotii) in Vietnam. A research study on the time budget, daily activity patterns, the influence of rainfall on activity and daily movement patterns of the Keeled Box Turtle (Cuora mouhotii) in Vietnam. Masters Thesis, Van Hall, Larenstein, Netherlands.

Fritz, U., ANDrEAs, B., AND LeHR, E. 1998. Eine neue Unterart der Driekiel-Scharnierschildkröte, Pyxidea mouhotii (Gray, 1862) (Reptilia: Testudines: Bataguridae). Zoologische Abhandlungen Staatliches Museum für Tierkunde Dresden 50:33-43.

Fritz, U.,Ziegler, T.,Herrmann, H.-W., AND LeHr, E. 2002. Intergradation between subspecies of Cuora galbinifrons Bourret, 1939 and Pyxidea mouhotii (Gray,1862) in southern North Vietnam(Reptilia: Testudines: Geoemydidae).FaunistischeAbhandlungen Staatliches Museum für Tierkunde Dresden 23:59-74.

Gong, S.-P., ShI, H.-T., Xu, R.-M., WANG,Z.-W., Xu, J.-P., ANd ZhanG, Y.-F. 2006. A survey of freshwater turtles in Jianfengling Nature Reserve, Hainan Province, China. Chinese Journal of Zoology, Peking 41:80.

Gong, S.-P.,CHow, A.T.,Fong,J.J., AND SHI,H.-T. 2009. The chelonian trade in the largest pet market in China: scale, scope and impact on turtle conservation. Oryx 43:213-216.

GraY, J.E. 1862. Notice of a new species of Cyclemys from the Lao Mountains, in Siam. Annals and Magazine of Natural History (2)10:157.

GraY, J.E. 1863. Observations on the box tortoises, with the description of three new Asiatic species. Proceedings of the Zoological Society of London 1863:173-179.

Guo, C.-W. 1997.A study on chromosomes of Chinese chelonians. In: Chinese Chelonian Research. Herpetological Series (9). Sichuan Journal of Zoology, 15 Supplement pp. 93-96. [In Chinese with English abstract.]

Hagen, C., Blanck, T., And Hudson, R. 2011. A visit to some food and petmarketsinsouthernChina. Turtle Survival Magazine 2011:80-81.

HENDRIE, D.B.2000. Status and conservation of tortoises and freshwater turtles in Vietnam. In: van Dijk, P.P., Stuart, B.L., and Rhodin, A.G.J. (Eds.). Asian Turtle Trade: Proceedings of a Workshop on Conservation and Trade of Freshwater Turtles and Tortoises in Asia. Chelonian Research Monographs No. 2, pp. 63-73.

Hoang, H.V., Thieu, Q.Q., Lai, C.T., Bui, P.D., and McCormack, T.E.M.2010. Radio telemetry study to investigate the environmental triggers to activity in the endangered Keeled Box Turtle (Cuora mouhotii) (Gray, 1862) in Cuc Phuong National Park, Vietnam, with a focus on student training and involvement in the study. Asian Turtle Program (ATP), Hanoi, Vietnam.

Hoang, H.V., Thieu, Q.Q., Lai, C.T., Bui, P.D., Hendrie, D.B., Bell, D., AND MCCORMACK, T.E.M. In press. Activity and habitat use in a tropical box turtle, the Keeled Box Turtle (Cuora mouhotii) (Gray, 1862) in Cuc Phuong National Park, Vietnam.

Honda, M., Yasukawa, Y., HiRayama, R., and Ota, H. 2002. Phylogenetic relationships of the Asian box turtles of the genus Cuora sensu lato(Reptilia: Bataguridae) inferred from mitochondrialDNA sequences. Zoological Science 19:1305-1312.

IvERSON, J.B. 1992. A Revised Checklist with Distribution Maps of the Turtles of the World. Richmond, IN: Privately Printed, 363 pp.

Iverson, J.B. AND MCCoRD, W.P. 1992. A new subspecies of Cuora galbinifrons (Testudines: Batagurinae) from Hainan Island, China. Proceedings of the Biological Society of Washington 105(3):433-439. JAKAB, P. AND SÁtORHELYI, T. 2000. Haltung und Zucht der Indischen Dornschildkröte Pyxidea mouhotii mouhotii (Gray, 1862) in men- 
schlicher Obhut. Emys 7(1):4-17.

King, F.W. AND Burke, R.L. 1989. Crocodilian, Tuatara, and Turtle Species of the World: A Taxonomic and Geographic Reference. Association of Systematics Collections, Washington, DC, 216 pp.

McCormack, T.E.M. 2005. Conservation of Vietnam's chelonians, the Keeled Box Tortoise (Pyxidea mouhotii)(Gray, 1862). Masters Thesis, University of East Anglia School of Biological Sciences Centre for Ecology and Conservation, Norwich, UK.

MCCORMACK,T.E.M.2015."Rua Mua Ban” arrested.One of Vietnams most active online traders of endangered turtles arrested in Hanoi, Vietnam. Asian Turtle Program Press Release.

McCormack T.E.M. and NGuyen, T.T. 2014. Busy year for turtle rescues in Hanoi, Vietnam. Asian Turtle Program Press Release.

McCormack, T.E.M.,NGUYen, X.T., ANd Hendrie,D. 2006.Assessing the potential of a localised conservation initiative focused on the critically endangered Indochinese Box Turtles (Cuora bourreti) Interview and field surveys in Song Thanh NR, Nam Giang district, Quang Nam province, Vietnam, June to July 2006. Asian Turtle Program (ATP), Hanoi, Vietnam.

McCormack, T.E.M., Le, M.T.T., HoAng, V.H., AND Le, D.M. 2011. Trade and field surveys of the turtle fauna of Ngoc Son Nature Reserve, Hoa Binh Province, Vietnam. Asian Turtle Program (ATP), Hanoi, Vietnam.

McCormack, T.E.M., Thanh, H.D., AND NGuyen, T.T. 2015. Critical confiscation of highly endangered tortoises need help in Vietnam. Asian Turtle Program Press Release.

McCormack, T.E.M., Bui, P.D., Hendrie, D.B., Thieu, Q.Q., Bell, D. In Press a. Season activity and home range in the Three Keeled Box Turtle(Cuora mouhotii): aSoutheastAsianforest-dependantspecies.

McDowell, S.B., JR. 1964.Partition of the genus Clemmys and related problems in the taxonomy of the aquatic Testudinidae. Proceedings of the Zoological Society of London 143:239-279.

MAUnG,W.AndKoKo,W.2002.Turtles andTortoises of Myanmar.Wildlife Conservation Society (Myanmar Program), Yangon, (5), 94 pp.

NabHitabHata, J., ChAN-ARD, T., ANd ChuAYNKERN, Y. 2000. Checklist of Amphibians and Reptiles in Thailand. Office of Environmental Ploicy and Planning, Bangkok, $152 \mathrm{pp}$.

NGuYen, T.T., McCormack, T., AND HoAng, V.T. 2013. Social media leads to transfer of endangered turtles to the Turtle Conservation Centre in Cuc Phuong National Park, Vietnam. Asian Turtle Program Press Release.

Parham, J.F., Simison, W.B., KozAK, K.H., Feldman, C.R, and Shi, H. 2001. New Chinese turtles: endangered or invalid? A reassessment of two species using mitochondrial DNA, allozyme electrophoresis and known-locality specimens. Animal Conservation 4:357-367.

Platt, S.G., Kalyar, and Ko Ko, W. 2000. Exploitation and conservation status of tortoises and freshwater turtles in Myanmar. In: van Dijk, P.P., Stuart, B.L., and Rhodin, A.G.J. (Eds.). Asian Turtle Trade: Proceedings of a Workshop on Conservation and Trade of Freshwater Turtles and Tortoises in Asia. Chelonian Research Monographs No. 2, pp. 95-100.

Platt, S.G., Platt, K., Myo, K.M., Moe, K., Soe, M.M., Naing, T.Z., Lin, N., AND RAINWATER, T.R. 2013. Noteworthy records of chelonians from the Chindwin River Basin and Naga Hills of Western Myanmar.Herpetological Conservation and Biology 8(2):335-350.

PoINTET, A. 1997. La tortue à trois carènes, Pyxidea mouhotii (Gray, 1862). CITS Bulletin 9:26-40.

Pope,C.H. 1935.The Reptiles of China.Natural History of CentralAsia. Vol. 10. American Museum of Natural History, New York, 604 pp.

Robiins, R.G., Phong, B.D., McCormack, T., Behler, J.L., ZwartePOORTE, H.A., HendrIe, D.B., AND CALLE, P.P. 2006. Four new host records for Amblyomma geoemydae (Cantor) (Acari: Ixodida: Ixodidae) from captive tortoises and freshwater turtles (Reptilia:
Testudines) in the turtle conservation center, Cuc Phuong National Park, Vietnam. Proceedings of the Entomological Society of Washington 108:726-729.

SACHSSE, W. 1973. Pyxidea mouhotii, eine Landbewohnense Emydide Südostasiens (Testudines). Salamandra 9:49-53.

Schilde, M. 2004. Asiatische Sumpfschildkröte. Die Familie Geoemydidae in Südostasien, China und Japan. Natur und Tier - Verlag, Münster, 192 pp.

ShI, H. ANd Parham, J.F. 2001. Preliminary observations of a large turtle farm in Hainan Province, People's Republic of China. Turtle and Tortoise Newsletter 3:4-6.

SHI, H., FAN, Z., Yin, F., AND YuAn, Z. 2004. New data on the trade and captive breeding of turtles in Quangxi Province, South China. Asiatic Herpetological Research 10:126-128.

Shi, H., Parham, J.F., Simison, W.B., Wang, J., Gong, S., and Fu, B. 2005. A report on the hybridization between two species of threatened Asian box turtles (Testudines: Cuora) in the wild on Hainan Island (China) with comments on the origin of 'serrata'-like turtles. Amphibia-Reptilia 26:377-381.

ShI,H.,PARham,J.F.,FAn,Z.,Hong,M., AND Yin,F. 2008. Evidence for the massive scale of turtle farming in China. Oryx 42)1):147-150.

Smith, H.M. AND James, L.F. 1958. The taxonomic significance of cloacal bursae in turtles. Transactions of the Kansas Academy of Science 61:86-96.

Sodhi, N.S., Posa, M.R.C., Lee, T.M., Bickford, D., KoH, L.P., AND BRook B.W. 2010. The state and conservation of Southeast Asian biodiversity. Biodiversity Conservation 19:317-328.

StruiJ, R.P.J.H. 2010. Significant breedings. Turtle Survival Magazine 2010:17.

StRUIJK, R.P.J.H. AND BLANCK, T.E.G. 2015. Cuora mouhotii mouhotii (northern keeled box turtle) and C. bouretti (Bourret's box turtle). Captive hybridization. Herpetological Review 46:206.

StruiJk, R.P.J.H. And BLAnck, T.E.G. 2016. A likely new natural hybrid form of "Cuora serrata" (Cuora picturata x Cuora mouhotii $o b s t i)$ and its presence in the wild in Phu Yen province, Vietnam. Herpetology Notes 9:73-80.

StruiJk, R.P.J.H., McCormack, T.E.M., NGuyen, T.T., Pham, T.V., Stumpel, J.B.G., WANG, J., AND AuER, M. 2016. Intergradation between Cuora mouhotii mouhotii (Gray, 1862) and Cuora mouhotii obsti Fritz, Andreas \& Lehr, 1998 with notes on the species' geographical distribution and phenotypic variation. Sauria 38:31-47.

StUART, B.L. AND PARHAM, J.F. 2004. Molecular phylogeny of the critically endangered Indochinese box turtle (Cuora galbinifrons). Molecular Phylogenetics and Evolution 31:164-177.

Stuart, B.L. And Platt, S.G. 2004. Recent records of turtles and tortoises from Laos, Cambodia, and Vietnam. Asiatic Herpetological Research 10:129-150.

Telecky, T.M. 2001. United States import and export of live turtles and tortoises. Turtle and Tortoise Newsletter 4:8-13.

Tikader, B.K. And Sharma, R.C. 1985. Handbook: Indian Testudines. Zoological Survey of India, Calcutta, $156 \mathrm{pp}$.

Turtle Conservation Coalition[Rhodin,A.G.J.,Walde,A.D.,Horne, B.D., van DiJk, P.P., Blanck, T., AND HudSOn, R. (EDs.)]. 2011. Turtles in Trouble: The World's 25+ Most Endangered Tortoises and Freshwater Turtles-2011. Lunenburg, MA: IUCN/SSC Tortoise and Freshwater Turtle Specialist Group, Turtle Conservation Fund, Turtle Survival Alliance, Turtle Conservancy, Chelonian Research Foundation, Conservation International, Wildlife Conservation Society, and San Diego Zoo Global, 54 pp.

Turtle Taxonomy Working Group (TTWG) [VAn DiJk, P.P., Iverson, J.B., Rhodin, A.G.J., Shaffer, H.B., AND Bour, R.]. 2014. Turtles of the world, 7th edition: annotated checklist of taxonomy, synonymy, distribution with maps, and conservation status. In: 
Rhodin, A.G.J., Pritchard, P.C.H., van Dijk, P.P., Saumure, R.A., Buhlmann, K.A., Iverson, J.B., and Mittermeier, R.A. (Eds.). Conservation Biology of Freshwater Turtles and Tortoises: A Compilation Project of the IUCN/SSC Tortoise and Freshwater Turtle Specialist Group. Chelonian Research Monographs 5(7):000.329-479.

van DiJK, P.P. and Palasuwan, T. 2000. Conservation status, trade, and management of tortoises and freshwater turtles in Thailand. In: van Dijk, P.P., Stuart, B.L., and Rhodin, A.G.J. (Eds.). Asian Turtle Trade: Proceedings of a Workshop on Conservation and Trade of Freshwater Turtles and Tortoises in Asia. Chelonian Research Monographs No. 2, pp. 137-144.

van DiJk, P.P., Stuart, B.L., And Rhodin, A.G.J. Eds. 2000. Asian Turtle Trade: Proceedings of a Workshop on Conservation and Trade of Freshwater Turtles and Tortoises in Asia. Chelonian Research Monographs No. 2, 164 pp.

van Rooljen, M. 1998. Nageslacht van de Maleise doornschildpad (Pyxidea mouhotii). De Schildpad 24(6):278-284.

WanG, J., GonG, S.P., Shi, H.-T., LiU Y.-X., ANd ZhaO, E. 2011. Reproduction and nesting of the Endangered Keeled Box Turtle (Cuora mouhotii) on Hainan Island, China. Chelonian Conservation and Biology 10(2):159-164.

WANGYAL, J.T., WANGCHUK, D., AND DAS, I. 2012. First report of turtles from the Himalayan Kingdom of Bhutan. Chelonian Conservation and Biology 11:268-272.

Wulfert, I. 2008. Haltung und Nachzucht von Pyxidea mouhotii (Dreikiel-Scharnierschildkröte (Gray, 1862)). Terraristika Hamm 30 NTV:2-32.

Zhou, T., Huang, C., McCord, W.P., and Blanck, T. 2006. Captive breeding of hard-shelled chelonians in China. Reptilia 2006:27-34.

ZHOU, Z. AND JiANG, Z. 2008. Characteristics and risk assessment of international trade in tortoises and freshwater turtles in China. Chelonian Conservation and Biology 7:28-36.

Ziegler, T. 2002. Die Amphibien und Reptilien eines Tieflandfeuchtwald-Schutzgebietes in Vietnam. Natur und Tier-Verlag, Münster, 342 pp.

\section{Citation Format for this Account:}

DAS, I.,McCoRmack, T.E.M., van DiJK, P.P.,HOANG, H.V., ANDSTRUIJK, R.P.J.H. 2016. Cuora mouhotii (Gray 1862) - Keeled Box Turtle. In: Rhodin, A.G.J., Iverson, J.B., van Dijk, P.P., Saumure, R.A., Buhlmann, K.A., Pritchard, P.C.H., and Mittermeier, R.A. (Eds.). Conservation Biology of Freshwater Turtles and Tortoises: ACompilation Project of the IUCN/SSC Tortoise and Freshwater Turtle Specialist Group. Chelonian Research Monographs 5(9):099.1-12. [doi:10.3854/crm.5.099.mouhotii.v1.2016; http://www.iucn-tftsg. org/cbftt/] 